Journal of Political Science
(A Peer-Reviewed, Open Access Journal and Indexed in NepJOL)
ISSN 2362-1273 (Print); ISSN 2773-8132 (Online)
Volume 21, Special Issue, August 2021
http://ejournals.pncampus.edu.np/ejournals/jps/
Published by
Department of Political Science, Prithvi Narayan Campus, TU, Pokhara, Nepal
Email: polsc@ pncampus.edu.np; URL: www.pncampus.edu.np

\title{
Women Representation in Nepalese Local Election 2017: Issues and Challenges
}

\author{
Sanju Manandhar \\ Kathmandu based Independent Researcher
}

Corresponding Author: Sanju Manandhar, Email: sanjumanandhar01@gmail.com

DOI: https://doi.org/10.3126/jps.v21i1.39283

Copyright 2021@ The Publisher and Author/s. The journal is licensed under a Creative Commons Attribution-ShareAlike 4.0 International License. (c) (i) (0)

Submitted 13 July 2021; Reviewed 15 July 2021; Accepted 28 July 2021; Published 20 Aug. 2021

\begin{abstract}
Democracy is for power and justice. Women's participation in politics is for achieving these twin goals. The main objective of this study is to reviews the women representation at Nepalese local in political domain. The essential data and information are collected from secondary sources. Reports, information, facts, figures, policies, acts and program published by Nepal Election Commission-2017 and other related sources reports are basically used in this paper. One of the key factors to ensure higher and meaningful participation of women in politics is these favorable (reservation) electoral provisions. The 2017 local elections were significant in advancing female political representation in Nepal. However, what has been achieved so far is not enough and continued concentrated action is essential. There are more issues and challenges to be resolve for fair and meaningful political participation of women. The women's representation in politics should not be just a numeric representation. It should rise in the societal awareness for women and build capacity of female leaders and ultimately helps in the overall development of the country.
\end{abstract}

Keywords: Constitution, election, local government, participation, women's representation

\section{Introduction}

Persistent inequality of women political participation and representation is a worldwide phenomenon. As per a recent data released by the UN Women, only 25 percent of the 


\section{Women Representation in Nepalese Local Election 2017: Issues and Challenges}

parliamentarians in the world are women (Acharya, 2021). Considering the political scenario of Nepal, women political representation is not satisfactory. Despite of years of political struggle, civil society lobbying and the promotion of progressive laws and policies in favor of women, women's representation and participation in the political arena in Nepal remains with considerable challenges. Even though female occupy more than half of the population in Nepal, the political representation is very low. The struggle of women for equality and political participation goes back more than a century. Nepali women's engagement in social, economic, and political freedoms have not been properly documented. The history of women's struggle for their freedoms is not well documented in Nepal because men were the writers of history (Dhungana, 2014).Women's participation in Nepali politics surfaced in the revolution against the oligarchy Rana regime in 1951. For protesting against the undemocratic royal proclamation of 1960, a group of women organizations openly waved black flags in a public procession and were imprisoned. Women's active participation in politics was noted later in the 1990 People's Movement where women from various regions and ideologies significantly contributed in the success for abolishing the party-less system and establishing the multiparty democratic system in the country (Everest Uncensored, 2008).

Similarly, hundreds of thousands of women collectively participated in 2nd people movement in 2006 resulting in the demolition of monarchy and declaration of Nepal as a Federal Democratic Republic. As a result, the new constitution of Nepal 2015, ensured $33 \%$ of seats, guaranteed to the parliaments and all other government positions as well as provision of male-female alternate seat provisions in the highest positions such as President and Vice President, Chief and Deputy Chief of Parliament (in both upper and lower houses), Mayor and Deputy Mayor where one of two must be female. Further, it has ensured inclusive provisions in all state structures. As a result, from the national and local elections of 2017, women have come to occupy $41.8 \%$ of political positions across the country. These electoral provisions ensure higher and meaningful participation of women in politics (TAF, 2017). The 2017 became a landmark year for Nepal as it conducted the first elections since the adoption of its new constitution 2015 and the first at local levels after more than 17 years under the federal republican political system. It was also a successful year in terms of women's political empowerment and social inclusion as it saw representation from women and marginalized voters and candidates.

The provincial elections of 2017 saw participation of women candidates in almost all of the major political parties, underscoring this as a historic moment in terms of gender inclusion. This was the first provincial and local election after the promulgation of the Constitution 2015 under the federal republican system. Women achieved their quota of 40.4 per cent mandated by the Nepal Election Commission, including the higher posts of mayor and deputy mayor, in which parties were required to include at least one, woman candidate in either of the posts. However, the candidacy and the elected representatives of men outnumbered women candidates (Upreti, Upreti, \& Yamuna, 2020).The current Constitution incorporates specific provisions to provide some political support to women. Despite special measures set by the government for women's political participation, women have not been benefited from such measures (Pradhan, 2005).In 2017 the country held its local election in two decades, electing a total of 35,041 local representatives across 753 local levels. Due to provision of new quota system in Nepali constitution 2015, the women's political participation has increased. The presence of women does not necessarily guarantee that women's interests are protected. The 'substantive representation' of women requires not only the presence of women representatives but require commitment and action.

Journal of Political Science, Vol. 21, Special Issue, August 2021 [34-48] 


\section{Women Representation in Nepalese Local Election 2017: Issues and Challenges}

The full participation of women in political and decision-making processes as candidates and elected representatives is crucial to democratic development. Ongoing debates about political finance rarely consider the impact of money on women's representation. Money is an essential and unavoidable part of elections but creates an additional barrier for women and other marginalized groups, given their limited access to and control of financial resources. In Nepal and many other countries, female candidates may need to raise more funds than their male counterparts to run competitively. It found that unequal access to funds for female candidates, reinforced by patriarchal attitudes of political stakeholders, adversely affects their political representation (Cantrell, Magnus, \& Bhatta, 2020).

Limbu (2018) in her study finds that all the interviewed female candidates came from political family background and except for few participants who had been active in party politics; personal connections played a crucial role in securing access to electoral ticket. There was a rampant search for female candidates to fill gender quota requirement. Consequently, women who were situated in close proximity to men with political power benefited the most. Such political privilege and personal connections, however, did not guarantee any protection against gender and caste-based discrimination that women candidates and party workers continue to face within their political parties, and in society at large.

Unlike their male counterparts, women elected leaders are confronted with making choices between what is perceived as their primary identity as a home maker/caregiver vs. a political leader. The deeply entrenched patriarchal social norms that define gendered expectations and roles where women are historically confined to performing their domestic roles seem to be undermining their newfound political identity. Engendering the formal political space that the elected women representatives have come to occupy will require intensive behavior change interventions targeting both men and women for redefining gender roles and behavior that are rooted in patriarchy (Barau \& Jerryll, 2017).

TAF (2018) found that $47 \%$ of surveyed women representatives stated that they have not been able to identify any problems or challenges at work. Still, 53\% representatives indicated that they faced some kinds of challenges or problems. Of the 53\% who identified problems cite time-management (19\%), financial problem (9\%), caste/gender-based discrimination (6\%), and transportation (3\%) among others as challenges in the exercise of their role. More women from rural municipalities have identified problems such as time management and transportation compared to urban municipalities. In terms of women's decision or influence to run for election, family members provided 'encouragement' in $13 \%$ of cases and husband/spouse in $8 \%$ of cases. The low percentage of women getting encouragement from husband/spouse as compared to the family members could be due to the reduced presence by husband/spouse because of out-migration or due simply to the hierarchy within the household where the husband/spouse's voice is secondary to that of the parents.

Representation of women in Nepalese local election 2017 is increased up to $40.9 \%$ due to affirmative action or reservation provision in constitution of Nepal 2015 but the women representation in political domain remains largely a tokenistic in nature and only limited to numeric representation. 


\section{Women Representation in Nepalese Local Election 2017: Issues and Challenges}

\section{Objectives and Methodology}

The main objective of the study is to review the women's representation at Nepalese local election held in 2017. This study also helps to understand the issues and challenges faced by Nepali women in political domain.

Exploratory descriptive research design is used in this study. This research article is primarily based on the secondary information collected from the previous works of various writers and scholars in the form of books, research paper, general articles published in the newspapers on the matter related to representation of women in local election 2017. The essential data and information are collected from secondary sources. Information, facts, figures published by Nepal Election Commission-2017 and other related published information like policies, acts and programmes, books, journals and reports are basically used in this paper.

\section{Literature Review}

Five types of arguments have been put forward to justify women's representation in parliament (Sawer, 2010). First, justice arguments advocate women's equal rights to participate in the public arena as men. Second, utility arguments put forward a number of benefits that women's participation can bring about, such as reduction in corruption and benefit to political parties. Third, deliberative democracy arguments urge women's participation in public decision-making and enriching public debate through women's perspectives and experiences. Fourth, symbolic arguments identify the symbolic effects of women's participation: uplifting their status as a group, raising women's aspirations, increasing their connection to politics and legitimizing the political institutions. Fifth, agency arguments claim that women have interests that are different from those of men and the presence of the former is needed to protect these.

In studies of women's political representation, the concept of critical mass is widely used. The debate on 'critical mass' in women and politics research can be traced back to influential works by Rosabeth Moss Kanter and Drude Dahlerup, which, respectively, analyze the experiences of women who are form small minorities in the corporate and political spheres.

Kanter (1977) developed the concept of critical mass theory, studying women's behaviors in an industrial sales force dominated numerically by men. She focuses on how group structures shape interaction contexts and influence particular patterns of male-female interaction and found that a relative number of women were crucial to their performance and efficiency in the corporations. In her study she categorized four group structures: uniform, skewed, tilted and balanced. Analysis of the two groups, skewed and tilted, is relevant here. The skewed groups are those in which there is male/female ratio of about $85 / 15$ and the tilted group has the ratio of perhaps 65/35. The study shows that a skewed group, the numerically dominant types, men, control the group and its culture. Women remain token participants and they are often treated as representatives of their category, as symbols rather than individuals. In a tilted group, however, minority members and women are potentially allies and can form coalitions, and they are strong enough to affect the culture of the group. Women begin to become individuals differentiated from each other as well as a type differentiated from the majority. 


\section{Women Representation in Nepalese Local Election 2017: Issues and Challenges}

Kanter argued that in skewed group women were subject to "the dynamics of tokenism."According to Kanter, tokenism is viewed as bringing on a variety of issues, including sexual harassment, performance pressures, role entrapment, and self-distortion; these factors collectively put women at a competitive disadvantage within the organization, decreasing their performance and asserting dominant-group solidarity. The study concluded by saying, merely adding a few women at a time to an organization is likely to give rise to the consequences of token status. Women (or members of any other underrepresented category) need to be added to total group or organization membership in sufficient proportion to counteract the effects of tokenism. Kanter's study assumed that skewed groups transitioned to tilted groups, when the minority group comprised 15 to 35 percent of total group population. However, it stated specifically that further research was needed to help determine the "tipping points" at which: (1) a person's status changed from "token" to full group member and (2) group types shifted from skewed to tilted.

The next major social science study to examine critical mass is extended Kanter's analysis of the study of women in politics, which is conducted by Drude Dahlerup. Dahlerup (1988) examined how women were able to influence political culture and policy outcomes as their minority status grew in proportion. She concluded her study by stating that the available empirical evidence simply did not support a relationship between specific percentages of women and changes in political culture and/or policy outcomes. It is not possible to conclude that these changes follow from any fixed number of women; In fact, she suggested that factors beyond numbers, particularly "generational change in attitudes towards women in public roles," better explained changes in the political landscape following the influx of women into the male-dominated profession. She also stated "the example of just a few successful women in top positions (e.g., as prime minister or president) may have contributed substantially to the change in the perception of women as politicians." With that in mind, Dahlerup stated: "we should look for critical acts, not for a critical mass."

Pitkin (1967) Pitkin's multifaceted conception of representation is well known and widely cited. Pitkin identifies at least four different dimensions of representation which are formalistic, symbolic, descriptive and substantive representation. Each view provides a different approach of examining representation. While there are important differences among the four, she maintains that the different dimensions are properly conceived as integral parts of a coherent whole.

Formalistic representation refers to the institutional arrangements (rules and regulations) that precede and initiate representation. This theoretical work tends to emphasize women decision makers' ability to speak for other women as a matter of shared gendered identity, even there are differences among women. In this framework, individual women from varied backgrounds can contribute different ideas and perspectives to debate and to decisionmaking. This theory often emphasize that women's interests are not merely a matter of objective circumstances or material conditions.

Symbolic representation refers to the extent that representatives "stand for" the represented with an emphasis on symbols or symbolization. Here what matters is not the symbol itself, but its power to evoke feelings or attitudes. Symbolic representation is concerned not with who the representatives are or what they do, but how they are perceived and evaluated by those they represent. Symbolic representation has been shown to affect a number of important political attitudes and behaviors among minority populations. Feelings of political efficacy, interest in politics, confidence in government, and evaluations of government 


\section{Women Representation in Nepalese Local Election 2017: Issues and Challenges}

officials have all been shown to be higher under conditions of symbolic representation (Abramson, 1972).

Descriptive representation refers to the manner in which an individual representative "stand for" the represented by virtue of sharing similar characteristics with the represented such as race, sex, age, class, occupation, gender, ethnicity or geographical area. Typically, this should mirror the composition of the represented in important respects. Women representing women can be seen as a form of direct participation in decision-making bodies. Women achieving descriptive representation is simply about counting the number of women in political office and not examining what women representatives are actually saying. Descriptive representation is a political resource along which social cleavages are stratified (Kurebwa, 2015). Descriptive representation is very useful in reducing inequality. So many governments, political leaders, social justice advocates, and researchers support its concepts.

Substantive representation is defined as acting in the interests of the represented in a manner responsive to them. The substantive representative is independent of physical or other characteristics and serves the interests of the community where he or she belongs to. Women's substantive representation is embedded in feminist theory about women's underrepresentation, male dominance and male prerogatives in defining what is political. The concept was born out of feminist scholarship dealing with how to change male dominance. This also implies that a term like "men's substantive representation", in contrast is meaningless. The concept of women's substantive representation only makes sense when embedded in feminist theory about changing male dominance. With the global focus on increasing women's political representation, for example, through the use of gender quotas, the subject of women's substantive representation has become even more salient (Kurebwa, 2015).

\section{Results and Discussions}

In Nepalese local election there were total 148,364 candidates. Among them 90,517 (61\%) were male candidates and 57,847 (38.98\%) female candidates. Total elected candidates were 35,034, including 20,705 (59.04\%) male candidates and 14,329 (40.96\%) female candidates. The results show that the election was high point for women elected leaders, it's all due to the constitution's new quota system. The question now, however, is whether that numerical representation actually translates into engendering Nepal's political process.

Table-1: Gender distribution of contested candidates and elected candidates according to province in local election 2017.

\begin{tabular}{|l|l|l|l|l|l|l|l|}
\hline S.N. & Province & \multicolumn{3}{|l|}{ No. of candidate members } & \multicolumn{3}{|l|}{ Total Elected Members } \\
\cline { 3 - 8 } & & Male \% & Female \% & Total & Male \% & Female \% & Total \\
\hline 1 & Province 1 & 60.85 & 39.15 & 25067 & 58.81 & 41.19 & 6043 \\
\hline 2 & Province 2 & 83.9 & 16.1 & 27248 & 41.15 & 58.85 & 6618 \\
\hline 3 & Province 3 & 62.36 & 37.64 & 23613 & 59.27 & 40.73 & 5792 \\
\hline 4 & Province 4 & 60.04 & 39.96 & 12655 & 58.9 & 41.10 & 3934 \\
\hline 5 & Province 5 & 60.88 & 39.11 & 23036 & 58.78 & 41.22 & 5133 \\
\hline
\end{tabular}


Women Representation in Nepalese Local Election 2017: Issues and Challenges

\begin{tabular}{|l|l|l|l|l|l|l|l|}
\hline & & & & & & & \\
\hline 6 & Province 6 & 60.91 & 39.09 & 12402 & 59.97 & 40.03 & 3687 \\
\hline 7 & Province 7 & 59.28 & 40.72 & 14343 & 59.0 & 41.0 & 3834 \\
\hline & Total & 61.01 & 38.98 & 148364 & 59.04 & 40.96 & 35041 \\
\hline
\end{tabular}

(National Election Comission, 2017)

In province no.1, total numbers of elected candidates are 6,043. Among them 58.81 percent are male and 41.19 percent are female. In province No.2, total numbers of elected candidates are 6,618. Out of them 41.15 percent are male and 58.85 percent are female. In province no. 3 or Bagmati Province; total numbers of elected candidates are5792.Among them 59.27 percent are male and 40.73 percent are female. In province no. 4 or Gandaki Province; total numbers of elected candidates are 3,934. Out of them 58.9 percent are male and 41.10 percent are female. In province no. 5 or Lumbini Province total numbers of elected candidates are 5,133. Among them 58.78 percent are male and 41.22 percent are female. In province no. 6 or Karnali Province, total numbers of elected candidates are3,687. Out of them 59.97 percent are male and 40.03 percent are female. In the province no. 7 or Sudur Pachhim Province, total numbers of elected candidates are 3,834. Out of them 59 percent are male and 41 percent are female. Among the elected candidates, gender inclusion in local government is quite high than allocated by the new Constitution 2015 as well as election manifesto 2074 of different political parties because, the Nepal Constitution 2015 as well as election manifesto 2014 of different political parties because, the Nepal Constitution 2015 mentioned that each and every political parties should have at least 33 percent women included in their political activities including election too (table 5).

Table-2: Distribution of elected members by position in Nepal, 2017

\begin{tabular}{|l|l|l|l|l|}
\hline Position & Male \% & Female \% & Total & Number \\
\hline Mayors & 97.24 & 2.76 & 100.0 & 254 \\
\hline Deputy Mayors & 6.18 & 93.82 & 100.0 & 275 \\
\hline Chairman & 97.34 & 2.63 & 100.0 & 418 \\
\hline Vice Chairman & 9.18 & 90.84 & 100.0 & 415 \\
\hline Ward Chairs & 99.28 & 0.78 & 100.0 & 6733 \\
\hline Open members & 98.12 & 1.86 & 100.0 & 12775 \\
\hline Women members & - & 100.0 & 100.0 & 6742 \\
\hline Dalit women members & - & 100.0 & 100.0 & 6568 \\
\hline
\end{tabular}

(National Election Comission, 2017)

Majority of male (97.24\%) are elected in Mayor, 97.34 percent in chairman, 99.28 percent in ward chair and 98.12 percent in open members. But higher percent female are elected in reservation quotas (Women and Dalit Women) and second position like 93.82 percent in Deputy Mayor and 90.84 percent in Vice Chairman. However, majority of female are elected in minor post i.e. ward members and deputy post.

The 2017 is considered as the mile-stone year for Nepal as it held its local election after two decades. This election ensures the higher number of women representation as quota system is introduced by constitution of Nepal 2015.At least 14,000 women were elected from the three phases of local election. As a result, women now occupy different posts as ward 


\section{Women Representation in Nepalese Local Election 2017: Issues and Challenges}

members, ward chairs and deputy chairs of rural municipalities and mayors and deputy mayors of municipalities.

Article 269 of the constitution states that, "There must be a provision of such inclusive representation in its executive committees of political parties at various levels as may be reflecting the diversity of Nepal." Clause 15 (4) of the Political Party Registration Act says: "A political party should have at least one-third women representation in all its committees." Despite such provisions, major political parties brought the inclusion agenda as the empty talks and seem unconcerned to the issue of women representation. Even the leading political party has very few female members in their Central Committee. Even after the promulgation of the constitution in 2015, the number of women of Nepal in the cabinet has not increased significantly. This shows how women of Nepal are viewed merely just as tokens for public representation.

Majority of women are thought to fit only for secondary roles, such as for deputy positions and that too, simply to satisfy the inclusion provision. Top leaders seem to be under the impression that women cannot take up leadership or win elections. Their representation is merely as subordinates. Despite an increased participation of women in politics over the past two decades or so, their progress in leadership positions continues to be hindered. This proves how just abolishing a tradition that forced women to follow men dead or alive still does not bring equality. Even if our constitution has many progressive provisions, they do not mean much if they are being openly flouted to give continuity to the patriarchal status quo (Adhikari, 2020). While tremendous opportunities exist for women's political participation in Nepal within the new political structure, this should translates into creating a substantive representation of women and political decision making (Barau \& Jerryll, 2017).

Undoubtedly, there are significant developments towards constructing inclusive space for women in political scenario. But unfortunately it is seen in initial observations from the practice that women elected leaders are still challenged by deep-seated gender expectations, questions on capacities, and often divisive political ideologies, caste, ethnicity, religion, and class. Women elected leaders are confronted with making choices between what is perceived as their primary identity as a home maker/caregiver vs. a political leader unlike their male counterparts. The deep rooted patriarchal social norms that define gendered expectations and roles where women are historically confined to performing their domestic roles seem to be undermining their newfound political identity. The communities' trepidation in accepting women as leaders is pervasive, and is a far greater drawback for the effective participation of women in politics, than any other capacity limitations the elected women leaders may have (Barau \& Jerryll, 2017).

\section{Issues and challenges}

Nepalese society is characterized by strong patriarchal culture, where women traditionally have been marginalized from participating in public life. Women's social status and relative equality with men varies among Nepal's various ethnic groups, regions and castes. Yet, their position is normally determined by patriarchal traditions, in which the predominant view is that women are subordinate to men and their role should be confined to the domestic sphere, where their main duties involve child raising and household chores (UNESCO, 2006).Along with discriminatory cultural practice, law poses major hurdles in achieving gender equality in Nepal. 


\section{Women Representation in Nepalese Local Election 2017: Issues and Challenges}

Patriarchal practices, which control these women's lives, are reinforced and prevalent in almost all sectors. Likewise, patriarchal mind set as profoundly present in the political parties. In all most all political parties all the leading roles and decision making seats are occupied by men. The law on political parties and electoral acts highlight on fair representation of women in parties' structures, but women politicians are not given fair and meaningful responsibilities. This shows either woman leaders are not taken seriously as a political entity. Women's effective participation indecision making is hindered by a pervasive male domination inside political parties. Among several male and female members in political parties, decisions are always made by a handful of senior and high caste male leaders. Women's opportunities within the political parties are determined on the basis of their loyalty and kinship to particular leaders, rather than their capabilities and performance. Although women are active, to varying extents, in all of the major political parties, most of which also have women's wings, women's representation in higher levels of the parties central or decision making committees almost negligible.

Nepal as a male dominated society there's a tendency of leaders to think that women aren't as capable as men. Therefore, they bring more men in their party. There are statements from parties to say that in principle they are inclusive of women, but they haven't been practicing what they talk about (NDI, 2008).Following the traditional and conservative belief that men are supposed to be a born leader, whereas, women are merely a home-maker and the lack of realization of the capabilities and potentials of women as political leaders by the mind-set of mal prejudice. Women's access to political and administrative decision-making positions have been minimal (less than 10 percent and 5 percent, respectively), due to the lack of access to education and economic resources, social expectations for exclusive household responsibilities, and restricted mobility, as compared to male counterparts (ADB, 1999).

In local election 2017 the "Mandatory" female representation at local level is a good start but women rarely in executive positions. Further sensitization on women's issues is necessary. Even though there has been some numerical improvement in the quantitative dimension as a result of the affirmative action/ positive discrimination, the overall participation of women in decision making and powerful positions is still very low (Rana, Shivakoti, \& Kachhyapati, 2009).

The political institutions do not give much space to women with opinions. The women in politics are mostly the close relatives of the male leaders, who are in the power position. Such an unashamed misuse of Proportional Representation (PR) election system has raised questions about the validity of such elections. Such political privilege and personal connections, however, did not guarantee any protection against gender and caste-based discrimination that women candidates and party workers continue to face within their political parties, and in society at large. The last Federal Parliament had the record number of 56 husband-wives or inter-relative pairs, representing in the name of ordinary and marginalized Nepalese women and men. Other few women, who are lucky to have risen to the prominence in political and other domains, either they hail from aristocratic families or from the elitists groups. Thus, the women representation in political domain remains largely as tokenistic in nature (Acharya, 2021). Despite the existence of women's wings in most political parties and also an Inter Party Women's Alliance, where women occasionally gather to discuss political issues, women politicians find it hard to raise issues of particular concern to women in the Constituent Assembly (Falch, 2010). 


\section{Women Representation in Nepalese Local Election 2017: Issues and Challenges}

According to one study conducted by Limbu (2018) there was a rampant search for female candidates to fill gender quota requirement. Rather than promoting their own women party workers, political parties were scouting for external candidates with influential political and educational background particularly for decision-making positions like deputy mayor and for that they relied on personal/political connections. Consequently, women who were situated in close proximity to men with political power benefited the most. Further, some women having political positions belonged to higher class and castes or were close relatives of male politicians and were largely subordinate to the male leaders (Kanel, 2014).

Although women have had the right to vote and to stand for election since1951, their voices have long been silenced in Nepal. Women have traditionally had little opportunity to participate actively in political life, with few or no women represented in the legislative, judiciary and executive bodies. Availability of quota system has given some relief to the discriminatory situation. It has opened up new opportunities for women to participate in decision making process in Nepal. Limited education and literacy capacity, along with a lack of political experience and knowledge about the political system, further impede many female politicians from participating effectively in the political process. An issue that influences women's roles and their ability to participate in politics is the perception that the increase in women's representation was primarily a response to legal requirements, and not a result of the political parties' determination to improve gender equality in political structures and decision making. According to several respondents, this has led to a widely held belief that female Constituent Assembly members have only been put there as tokens to fulfill the requirements. The status of women in Nepal remains very poor in terms of health, education, income, decision-making, and access to policy making. Violence against women is still common, and there are not enough women in professions. There are only few active women leaders in the leading position in politics, economy, civil society and social framework. The few women don't represent the population of ordinary grass-roots women of Nepal.

According to Hachhethu and Shrestha (2002) find that women inclusion in the political party committee or the elected bodies was merely symbolic. Even with the provision of 33 per cent participation of women in the CA, in some cases, the influence of women in the decision-making and constitution-building has been found to be limited. Men often do not acknowledge women participation in debates and discussions on general subjects (Rai, 2015).

Apart from several issues, lack of media coverage on the news related to women political leaders in another issue. The cause for it might be the Medias don't see or find any women politician as a political party ideologue, policy maker, communicator or a mass motivator. Big media house has never given the executive head position to any women despite such growth of social media (Acharya, 2021). Mainstream medias do not priorities and disseminate the news of the issues raised by the women leader which show women not being participative and which shows women not being active and participative in the major decision making process of general public eye. Women's representation in politics is gradually increasing, but there has not been a significant leap forward in line with the huge political changes. A closer look at the provision of 33 percent women's representation is implemented only in those areas where legal and constitutional tools compel political parties to do so. Otherwise, top political leaders are not ready to give due space to women in their own parties or in other state organs. This shows political parties are not committed to the 


\section{Women Representation in Nepalese Local Election 2017: Issues and Challenges}

principle of inclusion and only legal and constitutional mechanisms are driving them to accept some inclusion.

At the same time, economic resources required to fund incentives for party workers and voters is rooted in unequal gender dynamics as male politicians tend to have more control over their property and assets compared to female politicians and thus, the latter struggle to run high-cost political campaigns, which becomes mandatory for key political positions. Political analyst has raised the issue of quality of women in politics. The quality issue raised only in the case of women members is a bit unfair. Too often their capacity to participate in Parliament at quota levels has been questioned, rather than holding up for scrutiny the forms of discrimination and lack of opportunities that have underprepared women for equal participation. The influence of women in decision-making and constitution-building process remains limited. Though women have become successful in acquiring higher positions (e.g., President of Nepal, earlier Chief Justice of Supreme Court and Speaker of the Parliament), achievements not even possible to imagine two decades ago, the achievements attained thus far are not enough. Continued, concerted action among all actors is essential (Upreti et al., 2020).

There is substantive level of women participation in Nepalese local election 2017 which has set an example and inspiration to other women up to the grassroots level, which surely increased the confidence level of aspirant women to see themselves in the law making bodies of the country. At least some degree of sensitivity and changed mindset could be presumed in the 'male only' model of political leadership among majority of the political parties towards bringing more women within the political representative bodies of the countries (Acharya, 2013). Women all over the world have participated widely in political movements in times of crisis but, once the crisis is over, they are relegated again to the domestic arena (Barbara \& Chaudhary, 1994). Despite an increased participation of women in politics over the past two decades or so, their progress in leadership positions continues to be hindered, primarily by male leaders who are unwilling to make way or even choose qualified women. As a result, female politicians have often been sidelined by their male counterparts from leadership and decision-making roles, a pattern that reflects just how patriarchal Nepal still is. There are more women in politics, but few and far between at decision-making level (Shrestha, 2020).

Deep seated patriarchal mind set should be eliminated from root. Violence against women and limitation of women to domestic arena should be exterminated. Women lack of access to financing; weaker professional networks; and outside responsibilities that make it harder to take on punishing and unpredictable working conditions and therefore, financial strengthening of women is very vital. Beyond financing constraints, women face high social and cultural barriers to political participation. In particular, greater care obligations, reinforced by public perceptions of a "woman's role," severely undermine women's ability to run for public office. Increasing women's participation in leadership and decisionmaking has proven to be good for economic and social development around the world. Discriminatory laws, processes and practices result in greater barriers to educational and economic opportunities for women and girls. Consequently, women are less likely than men to have access to the education, contacts and resources needed to become effective leaders. Low number of ministerial and public official positions available can present additional barriers for women, especially when combined with unequal access to resources and inherently biased structures and regulations. So, there should be equal opportunities and equal access to resources, structure and regulation. 


\section{Women Representation in Nepalese Local Election 2017: Issues and Challenges}

The continued absence of women in decision-making and leadership further reinforces stereotypes, both amongst potential candidates and the general public, undermining efforts to build the skills, networks and confidence women need to change the game. Politicians who are in power should support deserving female candidates rather than favoring female in their family and relatives. Right through past few decades, capable women without good political connections have been passed over in favor of less deserving candidates with good connections. Engendering the formal political space that the elected women representatives have come to occupy will require intensive behavior change interventions targeting both men and women for redefining gender roles and behavior that are rooted in patriarchy. The media houses should not have discriminated and neglect the issues raised by women leader. It is obvious that one size doesn't fit all solution to gender inequality in politics. But there is plenty that can and should be done to ensure that women's voices are heard.

Despite of all these challenges that women face in political and electoral processes, they have demonstrated success in achieving higher participation in political positions. However, what has been achieved so far is not enough and continued concerted action among all actors is essential. Women's representation has been ensured in all level of elected bodies, but women's equal participation in all state mechanisms is far from ideal. Results show that there is a statistically significant positive relationship between the functioning of government and women political participation. In other words, countries with poor functioning of government are likely to have low levels of women political participation (Courage, Kapingura, \& Richard, 2019). Political spaces do not exist in isolation; rather they co-exist with other social, cultural and economic spaces. Importantly the unequal gender dynamics exist in the society should be eliminated. Social, political, economic empowerment of women is very crucial to the overall development of the any country.

\section{Conclusion}

Nepal has undergone lengthy and massive sociopolitical changes from Rana regime to Federal Democratic Republic. Even though the road for women towards political participation has not been easy, they have been quite successful over the last decade in securing their rights (Upreti et al., 2020).During the Panchayat era, only three seats were reserved for women; after the Jana Andolan I of 1990, the quota for women candidacy in parliament was raised to 5\%. Women were severely underrepresented in the cabinet and women politicians did not exceed 6\% at any time until 2007 (Lotter, 2017). Nepali women's representation in the legislative body (Legislature-Parliament), however, was dramatically increased to 32.8\% through the Constituent Assembly (CA) Election held in 2008. In the election, 191 women leaders $(33.2 \%)$ were elected out of 575 seats. Cabinet nominated 6 women out of 26 seats, resulting to 197 women members $(32.8 \%)$ in the legislative parliament. As a result, at the local level, 41 per cent of newly elected officials were women along with 34 percent Provincial assembly seats reserved for women. Although there is increase in women's representation in the state restructuring, women have been denied political power as much as they can. Women candidate are elected just to fulfill the quota marked by government. Still Nepali women are carrying the burden of living in the patriarchal society. There is still huge entrenched discrimination and lack of opportunities. Women have become successful in acquiring higher position such as President of Nepal, Chief justice of Supreme Court and speaker of parliament etc., but the achievement is not enough. The influence on the decision making position is still lacking. Women are mostly considered in supporting roles. 


\section{Women Representation in Nepalese Local Election 2017: Issues and Challenges}

Indicator of inclusive and equitable social development is visible and tangible presence of women in public life. To improve the political participation quotas are also important factors but efforts to improve female representation in politics have often focused on quotas and reserved shares. It is just limited to a numeric representation. What is really needed is approach that tackles the underlying, interconnected barriers that women face in getting nominated for elected office and conducting successful campaigns.

The adoption of a quota for women's representation in political institutions has been a crucial first step to open the doors for women to take part in decision making in Nepal. It provides women an unprecedented opportunity to have political participation and influence decision making. No doubt, gender quotas have symbolic value but to transform descriptive representation into meaningful engagement requires simultaneous interventions focus on creating wider socio-economic opportunities for women, addressing unequal gender division of labor both within and outside household arrangements, deconstructing internalized stereotypes and challenging paternalistic and undemocratic institutions including political parties. The presence of women in political spaces should not be numerical or symbolical it should be purposeful and meaningful.

\section{References}

Abramson, P. (1972). Political efficacy and political trust among black school children: Two explanations. Journal of Politics, 34(12), 1243-1275. https://doi.org/10.2307/2128934

Acharya, I. (2013). Challenges of Nepalese women in parliamentary elections. Tribhuvan University Journal, 28(1-2), 8-88. https://www.nepjol.info/ index.php/TUJ/ article/view/26219.

Acharya, N. (2021). Women's representation in politics: Just a tokenism. The Spotlight Nepal, 14(12). https://www.spotlightnepal.com/2021/02/06/womens-representationpolitics-just-tokenism/

Asian Development Bank (1999) Women in Nepal: Country briefing paper. https://www.adb.org/sites/default/files/institutional-document/32561/women-nepal.pdf

Adhikari, A. (2020). Women representation in politics merely tokenism in Nepal. https://thegeopolitics.com/women-representation-in-politics-merely-tokenism-innepal/

Barau, N., \& Jerryll, R. (2017). Nepal elections: More women have a seat at the Table, but will they have a voice?, The Asia Foundation. https://asiafoundation.org/ 2017/12/13/ nepal-elections-women-seat-table-will-voice/.

Barbara, N., \& Chaudhary, N. (1994). Women and politics worldwide. Yale University Press.

Beaman, L. (2007). Women politicians, gender bias, and policy-making in rural India. http://www.unicef.org/sowc07/docs/bea ᄀman_duflo_pande_topalova.pdf

Cammisa, A., \& Reingold, B. (2004). Women in state legislators and state legislative research: Beyond sameness and difference. State Politics and Policy Quarterly, $4(2), 181-210$ 


\section{Women Representation in Nepalese Local Election 2017: Issues and Challenges}

Cantrell, A., Magnus, O., \& Bhatta, M. (2020). The Cost of representation: A study of women's representation and political finance in Nepal. Nepal/ IFES.

Courage, M., Kapingura, F., \& Richard, M. (2019). Factors influencing women political participation: The case of the SADC region. Cogent Social Sciences, 5(1).

Dahlerup, D. (1988). From a small to a large minority: Women in Scandinavian politics. Scandinavian Political Studies, 11(4), 275-298.

Dhungana, R. K. (2014). Nepali hindu women's thorny parth to liberation. Journal of Education and Research, 4(1),39-57.

Everest Uncensored. (2008). Status of women in Nepal opinion. https://everestuncensored.org/status-of-women-in-nepal/.

Falch, A. (2010). Women's political participation and influence in post conflict Bureundi and Nepal. PRIO Paper. Oslo: PRIO. https://www.prio.org/Publications/Publication/?x=7259

Hachhethu, K., \& Shrestha, I. (2002). Women \& Governance.Shtrii Shakti.

Kanel, T. (2014). Women's political representation in Nepal: An experience from the 2008 Constituent Assembly. Asian Journal of Women's Studies, 20(4),39-62.

Kanter, R. M. (1977). Some effects of proportions on group Life: Skewed sex ratios and responses to token women. American Journal of Sociology, 82(5),965-990.

Kurebwa, J. (2015). A review of Hanna Pitkin's (1967) conception of women's political representation. International Journal of Scientific and Research Publications, 5(11). $50-60$.

Limbu, S. T. (2018). Researching women's political inclusion in the 2017 local elections: Some comments and findings. https://www.np.undp.org/content/nepal/en/home/ blog/ 2018/researching-women-s-political-inclusion-in-the-2017-local-elections-somecomments-and-findings.html.

Lotter, S. (2017). Gender gap, gender trap: negotiations of inter sectionality and patriarchy amongst women elites in Nepal. International Quarterly for Asian Studies, 48(2).97115 .

National Election Comission. (2017). Local election result 2017. Retrieved June 10, 2021. http://election.gov.np/election/np

National Democratic Institute (NDI) (2008). Assessing women's political party programs: Best practices and recommendations. https://www.ndi.org/sites/default/ files/ Assessing-Womens-Political-Party-Programs-ENG.pdf.

Orr, K., \& McAteer, M. (2004). The modernisation of local decision making: Public participation and Scottish local government. Local Government Studies, 30(2).

Pepera, S. (2018). Why women in politics? https://womendeliver.org/2018/why-women-inpolitics/. 


\section{Women Representation in Nepalese Local Election 2017: Issues and Challenges}

Pitkin, H. F. (1967). The concept of representation. University of California Press.

Pradhan, P. (2005). The status of women in political participatio in Nepal. Nepal Journal Online, 35(36).65-77.

Rai, J. (2015). Gender equality in politics in Nepal: The role of demo Findland Promote Gender Equality in Nepalese Politics. Diaconia University of Applied Sciences.

Rana, S. P., Shivakoti, G. K., \& Kachhyapati, S. (2009). Keeping the Beijing commitment alive: Nepal NGO report on Beijing+15. National Network for Beijing Review Nepal.

Rosenthal, C. (2000). Gender styles in legislative committees. Women and Politics, $21(2), 21-45$.

Sawer, M. (2010). Women and elections. In L. Lawrence, N. G. Richard, \& N. Pippa (Eds.), Comparing democracies, elections and voting in the 21th Century. Saga Publications.

Search for Common Ground (2017). Status of Women and Youth Leadership in Nepal (Findings from mini survey conducted in 2017). https://www.sfcg.org/wpcontent/uploads/2018/04/Report-on-Status-of-Women-and-Youth-Leadership-inNepal-20180211.pdf

Seo, G., Wenhao, H., Seung, H., \& Caleb, H. (2017). Conceptual review of under representation of women in Senior leadership positions from a perspective of gendered social status in the workplace: Implication for HRD research and practice. Human Resource Development Review, 16(1), 35-59. https://doi.org/10.1177/1534484317690063

Shrestha, E. (2020, March 8). There are more women in politics, but few and far between at decision-making level. The Kathmandu Post.

Asia Foundation (2018). Nepal's locally elected women representatives exploratory study of needs and capacity. https://asiafoundation.org/wp-content/uploads/2018/07/NepalsLocally-Elected-Women-RepresentativesExploratory-Study-of-Needs-and-CapacityAssessment.pdf

UNESCO. (2006). Forms and patterns of social discrimination in Nepal. https://un.info.np/Net/NeoDocs/View/1449

Upreti, B. R., Upreti, D., \& Yamuna, G. (2020). Nepali women in politics: success and challenges. Journal of International Women's Studies, 21(2),76-93. 